\title{
The Development of Independent Fiscal Institutions: Lessons from $\mathrm{CBO}$
}

\author{
BARry ANDERSON ${ }^{\mathrm{a}}$
}

JEL-Classification: H6

Keywords: debt, Congressional Budget Office, fiscal institutions

\section{Introduction}

In recent years, independent fiscal institutions (IFIs) have been created in many countries around the world. Prior to this recent expansion, only the Dutch Central Planning Bureau (CPB), started in 1945, and the U.S. Congressional Budget Office (CBO), started in 1974, existed. The reasons for this expansion are many ${ }^{1}$, but a few stand out, including:

- the growing complexity of fiscal policies and the need for greater transparency;

- the greater involvement of legislatures in budgeting;

- the exposure to underlying risks and long-term sustainability issues prompted by the recent financial crises; and

- the importance of objective, nonpartisan budget information to the implementation and evaluation of fiscal rules. ${ }^{2}$

Many countries that created new IFIs used the $\mathrm{CBO}$ as a model for the organization, size and functions of their IFIs. However, several countries found that just creating an IFI didn't guarantee that the IFI was integrated into the country's fiscal institutions and practices. In addition, some of the new IFIs didn't provide the objective nonpartisan budget information that they were designed to produce.

a Currently Deputy Director, National Governors Association in Washington, D. C.; formerly Head of the Budgeting and Public Expenditures Division, OECD, Acting Director of the U.S. Congressional Budget Office, and the Senior Career Official at the White House Office of Management and Budget. The opinions expressed in this paper are entirely those of the author.

1 See, for example, SсHick (2002).

2 See Anderson and Minarik (2006) for a brief description of the some of the information provided by $\mathrm{CBO}$ for fiscal rules in the U.S. as well as an analysis of the factors that should be taken into account during the consideration and design of fiscal rules. 
Specifically, several IFIs failed to develop into the kind of CBO-like institution that had been the intent of the legislatures that created them.

The purpose of this paper is see what lessons can be had from CBO's development in its early years to help identify those factors that are most important to develop and integrate IFIs into established fiscal institutions and processes. Lessons from $\mathrm{CPB}$ and other successful IFIs are also considered, but as many countries used $\mathrm{CBO}$ as a model, lessons from CBO's experience are emphasized. But before looking at lessons from $\mathrm{CBO}$, it is worthwhile to review some basic principles for IFIs that were developed recently by the Organization for Economic Cooperation and Development's (OECD) Working Party of Senior Budget Officials.

\section{Principles for Independent Fiscal Institutions}

At the $4^{\text {th }}$ Annual Meeting of OECD's Parliamentary Budget Officials and Independent Fiscal Institutions held in February, 2012, OECD proposed a set of principles for IFIs based on lessons and elements of good practice that have emerged from existing experiences. ${ }^{3}$ The proposed principles sought to address challenges that countries may face in "designing an enabling environment conducive to an IFI's performance and to ensuring and their long-run viability". Below is a slightly condensed version of OECD's proposed principles.

\section{Local Ownership}

- To be effective and enduring, an IFI should have broad national ownership, commitment, and consensus across the political spectrum. While a country seeking to establish an IFI will benefit from the study of existing models and experiences in other countries, models from abroad should not be artificially copied or imposed. Regional or international authorities may provide valuable support and protection, but an IFI should not be established pursuant to an external commitment without a strong local commitment already in place.

- Local needs and the local institutional environment should determine options for the role and structure of the IFI. Its basic characteristics, including specific protections, should be consistent with the country's legal framework, political system, and culture. Its functions should be determined by the country's fiscal framework and specific issues that need to be addressed. Design choices

3 OECD (2012).

4 Ibid., p. 6. 
may also have to take into account capacity constraints, particularly in smaller countries.

\section{Independence and Non-partisanship}

- Non-partisanship ${ }^{6}$ and independence are pre-requisites for a successful IFI. A truly non-partisan body presents its analysis from a non-political perspective, always strives to demonstrate objectivity and professional excellence, and serves all parties. Consistent with non-partisanship, IFIs should not have any normative policy-making responsibilities.

- The head of an IFI should be selected on the basis of merit and technical competence, without reference to political affiliation. Qualifications should be made explicit, including professional standing, relevant government or academic experience, proven competence in economics and public finances, and familiarity with the budget process.

- The head's term (as well as the process for dismissal for cause) should be clearly specified in legislation and should be independent of the electoral cycle.

- The IFI should have full freedom to hire and dismiss staff, consistent with local labor laws. Staff should be selected through open competition based on merit and technical competence and without reference to political affiliation. Conditions of employment should be along the lines of that of the civil service.

- To further enhance independence, the location of an IFI's offices should be physically separate from both the executive and the legislative offices.

\section{Mandate}

- The IFI mandate should be clearly defined in legislation, including the types of reports to be produced and associated timelines for their release.

5 Several countries (e.g. Sweden, Ireland, and Portugal) allow for non-nationals to serve as members of their fiscal councils (a form of IFI with relatively greater involvement in the selection of policies) thus increasing the pool of qualified candidates and reducing the risk of groupthink.

6 Note that "non-partisan" is much different from "bipartisan": the former connotes lack of a political affiliation; the latter connotes affiliation with both (or all) political parties. A unit that is bipartisan would attempt to present its analysis from the perspective of both (or all) political parties, whereas a unit that is non-partisan would not present its analysis from a political perspective at all. Clearly a non-partisan unit would be superior in presenting objective information. The director of such a non-partisan unit may be a member of a political party, but this does not make the unit itself partisan as long as the director is more of a technician than a politician, he or she operates the agency in a non-partisan manner, and the staff is composed entirely of technicians. 
- IFIs should be able to produce reports at their own initiative. Similarly, they should have the autonomy to determine their own work program within the bounds of their mandate.

- Clear links to the budget process should be established within the mandate. Typical tasks carried out by IFIs might include:

- economic and fiscal projections, with short-, medium-, and long-term perspectives;

- baseline projections (assuming unchanged policies);

- analysis of the executive's budget proposals;

- monitoring compliance with fiscal rules or official targets;

- costing of major legislative proposals; and

- analytical studies on issues in such areas as tax, employment, and health care.

\section{Resources}

- The resources allocated to an IFI should be commensurate with its mandate. The appropriation for an IFI should be published and treated in the same manner as the budgets of other independent bodies such as audit offices. Multiannual budgets may further enhance the IFI's independence and provide additional protection from political pressure.

\section{Relationship with the Legislature}

- Legislatures perform critical accountability functions. Regardless of whether an IFI is under the statutory authority of the legislature or the executive branch, mechanisms should be put in place to encourage appropriate accountability to the legislature. These may include:

- providing all reports to the legislature for scrutiny - preferably through the budget committee - and in time to contribute to relevant legislative debate;

- having the IFI head and senior staff make regular appearances before the budget committee;

- submitting the IFI's budget to the legislature for review; and

- providing a role for the budget committee in the appointment and dismissal of the IFI head.

- The IFI's role vis-à-vis the budget committee, other committees, and individual members in terms of requests for analysis should be clearly established in legislation. Requests from committees and sub-committees should be emphasized rather than allowing them to come from individual members or political parties. This is particularly true for those IFIs established under the jurisdiction of the legislature. 


\section{Access to Information}

- There is often asymmetry of information between the government and the IFI. This creates a special duty to guarantee the IFI full access in legislation to all relevant information - including methodology and assumptions underlying the budget and other fiscal proposals - in a timely manner and at no cost. The need to secure access to information is particularly important in countries with a traditionally high degree of opacity in public accounts and official projections.

- Restrictions on access to government information, if any, should be clearly defined in legislation. Appropriate safeguards should be put in place with respect to protection of privacy (for example, taxpayer confidentiality) and of sensitive information in the areas of national defense and security (such as security clearances for IFI staff).

\section{Transparency, Communication, and Evaluation}

- Full transparency of IFI work and operations protects its independence and builds credibility with the public.

- IFIs should develop effective communication channels from the outset. As an IFI's influence in fiscal policy-making is dissuasive, media coverage of its work can assist in fostering informed constituencies that may then exercise timely pressure on the government to behave transparently and responsibly in fiscal matters.

- IFI reports (including all underlying data and methodology) should be published and made freely available.

- The release dates of major reports should be formally established, especially in order to co-ordinate them with the release of relevant government reports. IFIs should be careful not to pre-empt government reports.

- IFIs should release their reports in their own name - including through their own independent website - rather than providing them to other government institutions who in turn would release them.

- IFIs should develop a mechanism for external evaluation of their work. 


\section{Lessons from $\mathrm{CBO}$}

The OECD principles provide a good reference to what is needed to design and create an independent IFI. However, maintaining an independent research unit that provides objective budgetary information to the legislature after it has been set up may be as difficult as establishing an IFI in the first place. In this regard, it may be useful to review some of the challenges that the Congressional Budget Office faced in its early existence compared to OECD's principles.

The $\mathrm{CBO}$ evolved from a small budgetary research unit in the U.S. Congress. The law that created the $\mathrm{CBO}$ (the Congressional Budget and Impoundment Control Act of 1974) provided only general guidance as to its functions. Although the $\mathrm{CBO}$ now performs a very broad list of functions, it was not clear at its inception exactly what work it would do and what work would be done by the staff of the budget committees that were created by the same Act. In fact, former CBO Director Bob Reischauer, who was the first person put on the payroll when the $\mathrm{CBO}$ was created, said that one view was to severely limit the $\mathrm{CBO}$ role:

What the [U.S.] House [of Representatives] wanted [when CBO was created] was basically a manhole in which Congress would have a bill or something and it would lift up the manhole cover and put the bill down it, and 20 minutes later a piece of paper would be handed up, with the cost estimate, the answer, on it. No visibility, [just] some kind of mechanisms down below the ground level doing this ... non-controversial [work], the way the sewer system [does]. (Nancy D. Kates, 1989)

The $\mathrm{CBO}$ was able to expand its functions far beyond what was stated in this quotation and beyond what was in its original legislation - and develop into a nonpartisan, independent, objective agency mostly consistent with the OECD principles - in large part because of the efforts of Alice Rivlin, its first director. Rudy Penner, CBO's second director, Bob Reischauer, and others who staffed $\mathrm{CBO}$ in its early years also contributed to the successful establishment and integration of $\mathrm{CBO}$ into the U.S. budget process.

CBO's early history is analyzed below using OECD's seven basic principles:

\section{Local Ownership}

- Regional and international influences were not an element in the creation and development of CBO, but who "owned" $\mathrm{CBO}$ within the U.S. Congress clearly was. Rivlin was able to maneuver $\mathrm{CBO}$ so that it was primarily responsible to

7 The early years of CBO are well documented in Joyce (2011). See also SсHICK (2008). Another valuable source is DAY (2003) who provides a more detailed description of CBO's early years in Chapter Two. 
the newly-formed budget committees, with lessor responsibilities to the tax and appropriation committees, and basically no responsibilities to other committees or individual members. She did this in part by providing information and analyses that were not elsewhere available, and in part by being responsive and timely to the right members at the right time. Three other Congressional agencies - the General Accounting Office (GAO), the Congressional Research Service (CRS), which is an arm of the Library of Congress, and the Office of Technology Assessment (OTA), which was terminated in 1995 - provided Congress with some form of budget information at that time. But Rivlin did a very good job of differentiating the work to be performed by the new CBO from the work provided by these three, particularly by emphasizing that none of them did regular cost estimates. In addition, she emphasized that the new $\mathrm{CBO}$ would not make recommendations like GAO, would not keep its reports private like CRS reports, which were generally not available to the public, and would cover a very broad range of issues not just the technology issues covered by OTA. Rivlin also stressed coordination between the four institutions, which she effectively implemented after $\mathrm{CBO}$ was operational.

- The fact that CBO had a strong and influential supporter in the U.S. Senate, Senator Pete Domenici, was also very important in CBO's early years.

\section{Independence and Non-partisanship}

- Perhaps ironically, Rivlin was able to firmly establish CBO's non-partisanship through early reports that "pissed off" both major U.S. political parties, including some of CBO's strongest supporters. Although some members didn't like what the reports had to say, they soon accepted the CBO's work as unbiased.

- Another factor supporting CBO's independence was how Rivlin handled patronage: any Member of Congress was free to recommend people for $\mathrm{CBO}$ to hire, but $\mathrm{CBO}$ quickly established that it was free to not hire them.

- Rivlin took advantage of an opportunity to locate the unit's offices in an unpretentious building a short distance away from the U.S. House of Representatives office buildings. This location was a longer distance from the Capitol building and the Senate office buildings, but the physical separation was never allowed to impact the prompt responsiveness of the CBO staff to meet with House or Senate members and staff.

\section{Mandate}

- Joyce (2011) and DAY (2003) document how unclear CBO's mandate was at the beginning. Issues such as the type of reports expected from $\mathrm{CBO}$, whether 
$\mathrm{CBO}$ could produce work on its own initiative, the manner by which $\mathrm{CBO}$ reports were released, and staffing and budget levels were hard fought from the very start. But Rivlin was able to clarify CBO's mandate through persistence, her ability to play one side off against the other, and her (and subsequent $\mathrm{CBO}$ directors) "luck" of having the Executive Branch provide ample opportunities that would highlight CBO's non-partisan, objective, independent (and frequently more accurate) estimates, projections, and analyses.

\section{Resources}

- CBO's budget has been carefully scrutinized since its foundation. Moreover, it has been held to an annual budget even after it was widely recognized as providing Congress and the public with valuable and useful budget information.

- There have been repeated attempts over the years from a few members to "punish" $\mathrm{CBO}$ for something it said by cutting its budget. But by developing a broad base of services to a wide variety of members, $\mathrm{CBO}$ has been able to maintain relatively stable funding over the years.

- That said, the demands on CBO staff for cost estimates and analyses have always exceeded the staff available to do them. Only through careful management of requests - few if any responses to individual members; balancing requests from partisans of a certain policy by obtaining requests from partisans of the opposite policy - has CBO been able to balance its incoming requests with its staff availability.

\section{Relationship with the Legislature}

In addition to what has been mentioned above, several other factors have helped $\mathrm{CBO}$ in its relationship with the Congress:

- How CBO transmitted bad news: the "no surprises" rule. Budgeting and bad news seem to go together, but early on CBO developed a policy to give the relevant committee chairman and members a verbal heads up (but not the report itself) when a soon-to-be-released $\mathrm{CBO}$ report was going to contain information that could be interpreted as contrary to the member's views. This early warning allowed members to respond quickly and informatively to the release of a $\mathrm{CBO}$ report, especially if they didn't like or agree with what the report had to say. In sum, $\mathrm{CBO}$ has benefited not by trying to change or soften what it says, but by warning those most affected by it in advance.

- Responsiveness. One major criticism that legislators around the world have is how unresponsive presidents and prime ministers are to their requests. CBO realized this applied to the U.S. Congress too, and thus it has always tried to be timely with its products. In particular, it has sought to distinguish how it 
responds to requests from how the Executive Branch responds to Congressional requests.

- Availability of reports. By putting all its work and the assumptions and methods used to produce the work on the web, CBO has clearly established itself as open and transparent. This greatly helps the perception that $\mathrm{CBO}$ does not play favorites in the Congress.

\section{Access to Information}

- With very few exceptions, Congress has supported CBO's access to information from executive branch agencies. Tax data and national security information have frequently been limited to only those CBO staff with proper authorizations, but the data has generally been made available without problem.

\section{Transparency, Communication, and Evaluation}

- There were some members of Congress who were very concerned about CBO becoming a policy spokesman for the Congress. Some of Rivlin's many initial public appearances highlighted this concern. But because Rivlin and subsequent $\mathrm{CBO}$ directors made their public appearances more technical than political, and because $\mathrm{CBO}$ did not make recommendations, this concern was mostly alleviated. Although some recent $\mathrm{CBO}$ directors have assumed very political positions after leaving $\mathrm{CBO}$, generally all $\mathrm{CBO}$ directors have recognized the importance of emphasizing CBO's technical work. In this regard, $\mathrm{CBO}$ directors strive to supply the budget committee chairmen and other members with $\mathrm{CBO}$ work that assists political officials - not $\mathrm{CBO}$ directors or staff - in making policy statements.

- It is also relevant to note than from the very beginning, $\mathrm{CBO}$ has provided the same information to both political parties, no matter who was in the majority or minority.

- Similarly, from the very beginning, $\mathrm{CBO}$ has sought to coordinate with the budget committees the timing of its reports. However, because the timing of the release of a report can sometimes have as much political significance as the content, $\mathrm{CBO}$ has retained the final say over release dates - something it has not always done well.

- CBO also developed a policy of being willing to meet with lobbyists or other proponents of policy proposals. But in doing so, $\mathrm{CBO}$ has gone out of its way to also meet with the proposals' opponents, keeping in mind that a fair and balanced process - both in fact and in appearance - is of utmost importance.

- How CBO handled transparency has been mentioned above, but it is worth emphasizing that the degree of transparency (everything - cost estimates, 
reports, analysis, assumptions, models - on the web as soon as possible, and making CBO staff available to testify and to brief Congressional staff) far exceeded anything else provided by other agencies. As a perhaps unintended result of this transparency, the media love $\mathrm{CBO}$, as does the international community.

- De facto evaluations of $\mathrm{CBO}$ come generally from oversight hearings and from academia.

\section{Applicability of CBO's Experiences to Other IFIs}

There are many unique aspects to the creation and development of CBO. Nevertheless, as other countries create and develop their own parliamentary budget offices, fiscal councils, or other types of independent fiscal institutions, some of the early experiences of the founders of $\mathrm{CBO}$ could be relevant to IFIs around the world.

Non-partisanship is much more difficult to develop and maintain in practice than it is in theory.

- From its inception, $\mathrm{CBO}$ has not tried to please any faction - neither its supporters nor its opponents. The willingness to "piss off" anyone - and everyone - may have done more to establish and maintain its non-partisanship nature than any other action.

\section{Recommendations hurt the perception of objectivity.}

- GAO makes recommendations; CBO doesn't. This alone may have helped CBO develop a reputation as not just non-partisan, but also as objective. (Related to this: avoid patronage.)

The limelight may feel good, but it clearly hurts the acceptability of an IFI.

- Politicians are elected to make policies and be in the limelight; IFI heads aren't. $\mathrm{CBO}$ has prospered the more it operates in a responsive manner to requests of Members of Congress as opposed to trying to lead them.

Consistent with the above point, personalities matter.

- Alice Rivlin was a consummate technician who by her stature was non-threatening. Her personality, as well as her judgments, was instrumental in developing a non-partisan independent objective CBO. (But even she did better the more she avoided the limelight.) Her immediate successors - Rudy Penner and Bob Reischauer - continued to maintain CBO's credibility. 
Lastly, an unpretentious nature helps - not only for the head, but also for the staff and for the whole location and operation of the IFI.

- CBO has always had a "cheap chic" atmosphere: it is located in a nondescript office building removed from the Congress, and nobody gets rich working for $\mathrm{CBO}$. And unlike some of the heads of OMB, CBO directors are only very rarely mentioned on the Style pages of the Washington Post. This atmosphere promotes an esprit de corps among staff, and fosters independence and objectivity. In addition, it certainly does not induce envy.

As important as these items are, they do not include some other important elements in developing $\mathrm{CBO}$ that were perhaps taken for granted in the U.S., but have been problematic in other countries. These elements include:

- Reporting directly to the Congress, not through some intermediary institution; ${ }^{8}$

- Being able to develop credibility very early, in part because of the lack of credible budget information coming from the executive branch;

- Being very lucky or having the foresight to being able to withstand the first change in government; ${ }^{9}$

- Having a good pool of qualified analysts to stock $\mathrm{CBO} ;{ }^{10}$

- Wisely using advisory boards; ${ }^{11}$

- Relating independence with lack of interference. ${ }^{12}$

In sum, after reviewing the OECD principles and the experiences of $\mathrm{CBO}$ and other countries in applying those principles, the importance of the personality of the first head of an IFI can't be overestimated. Having a head who is simultaneously a forceful advocate for the agency but also primarily a low-key technician who avoids the limelight seems to be the most important factor in determining an IFI's future success.

8 For an assessment of the Canadian PBO, see Jeffrey (2010) and Page and Yalkin (2012).

9 See, for example, a description of the experiences of the Hungarian Fiscal Council in Kopits (2011).

10 See Page and Yalkin (2012).

11 See Calmfors and Wren-Lewis (2011).

12 See Hagemann (2011). 


\section{References}

Anderson, Barry, and Joseph J. Minarik (2006), "Design Choices for Fiscal Policy Rules", OECD Journal on Budgeting, Vol. 5, No.4.

Calmfors, Lars, and Simon Wren-Lewis (2011), "What Should Fiscal Councils Do?", OECD $3^{\text {rd }}$ Meeting of Parliamentary Budget Officials, Stockholm.

Day, Dwayne (2003), "Gourmet Chefs and Short Order Cooks: A Policy History of the Congressional Budget Office, 1975-2001", unpublished manuscript.

Hagemann, Robert (2011), "How Can Fiscal Councils Strengthen Fiscal Performance?", OECD Journal: Economic Studies.

Jefremey, Brooke (2010), "The Parliamentary Budget Officer Two Years Later: A Progress Report", Canadian Parliamentary Review, 33, pp.37-45.

Joyce, Philip G. (2011), The Congressional Budget Office: Honest Numbers, Power, and Policymaking, Washington, DC : Georgetown University Press,.

Kates, Nancy D. (1989), "Starting from Scratch: Alice Rivlin and the Congressional Budget Office”, Case program C16-88-872.0, John F. Kennedy School of Government, Harvard University, Cambridge, Massachusetts.

Kopits, George (2011), "Independent Fiscal Institutions: Developing Good Practices", OECD, $3^{\text {rd }}$ Meeting of Parliamentary Budget Officials, Stockholm. OECD (2012), "Draft Principles for Independent Fiscal Institutions", Background Document No.3.

Page, Kevin and Tolga R. Yalkin (2012), "The Canadian Parliamentary Budget Office: Oversight with Qualified Independence”, unpublished draft.

Schick, Allen (2002), "Can National Legislatures Regain an Effective Voice in Budget Policy?", OECD Journal on Budgeting, 1(3).

Schick, Allen (2008), The Federal Budget: Politics, Policy, Process, Washington DC : Brookings Institution Press. 